\title{
Från motsatsförhållande till symbios? Miljöpolitik och välfärd i ekonomiska upp- och nedgångar
}

\author{
Karin Edberg
}

SAMMANDRAG: Globala utmaningar som klimatförändringar, transnationella kapitalrörelser och politiskt gränsöverskridande samarbete har satt den nationella välfärdsstaten på prov under de senaste decennierna. Två större finansiella kriser har också de påverkat politikens utformning. Under samma tid har begreppen hållbar utveckling och ekologisk modernisering bidragit med ståndpunkten att tillväxt och miljömedvetenhet kan gå hand i hand. Utifrån den kontexten diskuterar Karin Edberg i sin artikel huruvida miljöpolitiken kan sägas vara en del av den nutida svenska välfärdsstaten. Till grund för sitt resonemang använder sig Edberg av de årliga regeringsförklaringar som ges av statsministern i samband med riksdagens öppnande. Detta innebär att artikelns resultat inte speglar politisk praktik utan snarare vilka frågor som anses vara i den politiska hetluften och hur de artikuleras. Edberg visar hur miljöfrågan pendlat mellan att utgöra en avideologiserad och normaliserad del av det politiska landskapet, och en politisk vattendelare. I dag är idén om hållbar utveckling kittet som binder samman miljöpolitiken med välfärdsstaten - åtminstone på en retorisk nivå - och som gör miljö till en konsensusfråga.

NYCKELORD: välfärdsstat; miljöpolitik; ekonomisk tillväxt; ekonomisk kris; hållbar utveckling; ekologisk modernisering.

PUBLICERINGSHISTORIK: Originalpublicering.

KARIN EDBERG är doktorand i sociologi vid Södertörns högskola.

E-POSTADRESS: karin.edberg@sh.se

FÖRSLAG PÅ KÄLLANGIVELSE:

Edberg, Karin (20I6) "Från motsatsförhållande till symbios? Miljöpolitik och välfärd i ekonomiska upp- och nedgångar", i Arkiv. Tidskrift för sambällsanalys, nr 6, s. 7-37. DoI: http://dx.doi.org/IO.I3068/2000-6217.6.I

(C) Karin Edberg/Arkiv förlag \& tidskrift 2016 (publicerad 7 oktober 20I6)

Artikeln distribueras enligt en upphovsrättslicens från Creative Commons: Erkännande-Ickekommersiell-IngaBearbetningar 3.o Unported, som medger fri ickekommersiell användning och spridning i oförändrat skick så länge källan anges. 
Arkiv. Tidskrift för samhällsanalys är en sakkunniggranskad vetenskaplig tidskrift för samhällsvetenskap och historia. Samtliga artiklar publiceras fritt tillgängliga på:

$$
\text { www.tidskriftenarkiv.se }
$$

Beständig länk, DoI: http://dx.doi.org/IO.13068/2000-62I7

Den här artikeln finns tillgänglig i följande format:

PDF \& HTML: via beständig länk, DOI: http://dx.doi.org/IO.I3068/2000-62I7.6.I EPUB: ingår i e-boksutgåva av numret, ISBN: 978 9I 79242794 TRYCK: ingår i bokutgåva av numret, ISBN: 978 9I 7924280 O

Grafisk utformning och sidnumrering är identisk i pdf och tryck.

Samtliga artiklar i nr 6 (20ı6) nås via beständig länk, DOI: http://dx.doi.org/I0.13068/2000-6217.6

Arkiv. Tidskrift för samhällsanalys ISSN: 2000-62I7 (för elektronisk resurs) ISSN: 2000-6225 (för tryckta nummer)

ges ut av

Stiftelsen Arkiv för främjande och spridning av samhällsvetenskaplig och historisk forskning

genom

Arkiv förlag \& tidskrift

Box 1559

SE-22I OI Lund

ВESÖK: L Gråbrödersg 3 c, ipg

TEL: 046-I3 3920

ARKIV FÖRLAG: arkiv@arkiv.nu·www.arkiv.nu

TIDSKRIFTEN ARKIV: red@tidskriftenarkiv.se · www.tidskriftenarkiv.se

ANSVARIg UTGIVARE \& CHEFREDAKTÖR: Sven Hort

ADMinistrativ RedaKtör: David Lindberg

ReDAKTörer: Paavo Bergman, Lisa Kings, Zhanna Kravchenko 


\title{
Från motsatsförhållande till symbios? Miljöpolitik och välfärd i ekonomiska upp- och nedgångar
}

\author{
KARIN EDBERG
}

\section{Inledning}

Den svenska välfärdsstaten är välkänd och ökänd liksom omtyckt i stora delar av världen. Den har tidvis anklagats för att hindra befolkningens fria vilja, utöva ett förmyndarskap och kväva olikhet genom högt skattetryck och likriktning. Samtidigt framställs den som ett gott exempel på hur klyftor kan överbryggas och välstånd uppnås. Sedan välfärdsstaten grundades har det betonats att välfärd kräver tillväxt. Dock har det ända sedan 1970-talet framhållits att detta innebär ett dubbelt problem eftersom välfärdsstaten har att handskas inte bara med att underlätta ekonomisk tillväxt och konkurrens, utan också med att säkerställa invånarnas välmåga och en hållbar användning av naturresurser (Eckersley 2004). Detta har ställts på sin spets under de senaste decennierna när globala dilemman som klimatförändringar, ett alltmer transnationellt kapital och migrationsströmmar har satt välfärdsstaten på prov.

Dagens politiska diskurs placerar dock inte längre miljömedvetenhet och klimatanpassning i motsatsrelation till ekonomisk tillväxt. I stället beskrivs miljövänlig produktion och konsumtion ofta som nyckeln till tillväxt. Detta paradigmskifte skedde i och med lanseringen av begreppen "hållbar utveckling" och "ekologisk modernisering", vilka har haft stor betydelse för utvecklingen av den svenska miljöpolitiken och på sättet som den inlemmats i välfärdsretoriken (Anshelm 2000; Lundqvist 2000; 
Lidskog \& Elander 20I2; Sommestad 20I2). Även om definitionerna av hållbar utveckling är många och inte alltid överensstämmande (Hajer 1995), är den bärande tanken bakom begreppet att en långsiktig omsorg om sociala och ekologiska värden inte är ett hinder för ekonomisk tillväxt utan snarare kan fungera som en motor för densamma.

Ekologisk modernisering ser miljöproblem som ett resultat av det moderna samhället, men menar att de kan lösas inom befintliga samhälleliga strukturer och att miljöarbete lönar sig ekonomiskt (Hajer 1995; Medina 20I3). Vidare brukar ekologisk modernisering ofta karaktäriseras som en teori med hög tilltro till tekniska innovationer och marknadslösningar (snarare än statliga interventioner) för att nå ekologisk hållbarhet, även om teorin i senare utvecklingsfaser rört sig mot en mer nyanserad inställning i de frågorna (se t.ex. Mol 1999; Mol \& Spaargaren 2000). Då ekologisk modernisering lutar sig på befintliga samhälleliga relationer och konstellationer krävs inga stora förändringar av det existerande socioekonomiska systemet för att nå de gröna målsättningarna, vilket gör det attraktivt för beslutsfattare.

Paradigmskiftet gjorde att den svenska socialdemokratin kunde göra frågan till sin på I990-talet genom att skapa utopin om "det gröna folkhemmet". Detta gjorde att en ideologisk diskussion om politikens respektive marknadens roll i miljöfrågan väcktes till liv (Anshelm 1995, 2002). $\mathrm{Nu}, 20$ år senare, har dock frågan återigen avideologiserats. Som jag visar i den här artikeln säger sig politiker från hela den politiska skalan alla vara förkämpar för miljö och hållbar utveckling. En liknande utveckling har skett i frågan om välfärden, vilket omskapandet av Moderaterna till ett mer socialkonservativt parti påvisar.

Miljö, och då i synnerhet storskaliga frågor såsom mänsklig påverkan på klimatet, har blossat upp som en av vår tids största frågor. Dessutom har miljöfrågorna blivit alltmer globala till sin karaktär vilket föranleder samarbeten över nationsgränser, vilket innebär nya utmaningar för den traditionella välfärdsstaten. Statens roll kan komma att förändras när transnationella policyer och marknadsinstrument får allt större genomslag i nationell och lokal politik, EU:s inflytande på svensk politik ökar och det internationella samfundet i form av FN spelar en allt viktigare roll även nationellt. Sverige måste förhålla sig till internationella och 
regionala målsättningar och politiska trender - och vill ofta framstå som ett land i framkant för att lösa världens problem, inte minst vad gäller miljöfrågor. Traditionellt hanterar välfärdsstaten olika sociala risker genom vård, omsorg, utbildning och arbetsmarknadsåtgärder. Men kan moderna, globala påfrestningar i form av miljöförstöring, klimatförändring och energiomställning sägas ingå i vad dagens välfärdsstat ska hantera, och vilka instrument kan staten använda för att bemöta dessa risker? Oavsett svaret upptar frågan i dag ett stort utrymme i den politiska retoriken. Den här artikeln syftar till att beskriva och analysera på vilket sätt klimat- och miljöfrågor inkluderas i välfärdspolitiken och hur de motiveras i förhållande till den tillväxt som ses som en förutsättning för denna politik.

Under samma period som den politiska retoriken har gått från att ställa miljö i motsättning till välfärd till att se de två begreppen som ömsesidigt främjande har Sverige genomgått två omfattande perioder av ekonomisk kris: 1990-talets finansiella kris och den så kallade eurokrisen som följde på den amerikanska bankkrisen 2008. Lanseringen av det så kallade gröna folkhemmet framställdes som en del av lösningen på den ekonomiska lågkonjunktur som skakade Sverige i början av I990-talet. Det hävdades att med en satsning på grön teknologi och andra miljöfrämjande åtgärder skulle Sverige kunna bygga sig ur krisen, på samma sätt som man gjort med bostäder på 1960-talet (Anshelm 1995, 2002). Artikeln frågar sig därför om samma förhoppningar sätts till miljöpolitiken i samband med den senaste krisen. 20Io-talet präglas av en segdragen finansiell lågkonjunktur som förutom en stagnerad marknad, ett försvagat EU-samarbete och ökade klyftor även påverkat satsningar inom miljöområdet. Tidsmässigt är studien avgränsad till 1900-talets två sista och 2000-talets två första årtionden. Syftet är att undersöka hur miljöproblem uttrycks i den svenska politiken innan, under och efter tider av finansiell oro - om och i så fall hur "grönt tänkande" ses som en väg ut ur krisen, och hur miljöpolitiken relateras till den för välfärden viktiga tillväxten. Därtill om politiken anser miljön vara en fråga för marknaden, individen eller staten att hantera. Min analys visar att under denna period vidgas välfärdsbegreppet rumsligt och tidsmässigt i och med inkluderingen av miljö i dess intresseområde, och att välfärds- 
statens utveckling därmed är sammanknuten med, och påverkas av, det som händer på miljöområdet.

Artikelns empiri består till största del av de årliga regeringsförklaringar som görs av statsministern inför riksdagens öppnande varje höst. Dessa tal har karaktären av egen genre och kan tyckas vara svepande, kortfattade och utan tydliga svar på hur de avhandlade frågorna ska omsättas i praktik. En annan kritik är att de bara speglar åsikter hos partier i regeringsställning. Likväl menar jag att de ändå ger tydliga fingervisningar om vad som är på den politiska agendan för tillfället och vilka frågor regeringen känner sig nödgad att lyfta. Vidare bygger analysen på policydokument från EU och från svenska beslutsfattare såsom visionsdokument från de största riksdagspartierna. Under början av 1990-talet liksom under slutet av 2000- och början av 20IO-talet regerade en borgerlig allians Sverige. Därför är det mest deras politik som speglas i materialet. Dock är de rödgröna partierna, och då speciellt Socialdemokraterna, viktiga aktörer eftersom de ledde landet före, mellan och efter krisperioderna. De har introducerat viktiga reformer och strategier på miljöområdet och har samarbetat i blocköverskridande koalitioner för att få bukt med finansiell oro. ${ }^{1}$

Artikeln är upplagd på föjande vis. Först görs en historisk tillbakablick över vilken roll miljöpolitiken har haft i svensk politik och dess relation till välfärds- och tillväxtpolitiken generellt. Nästa avsnitt handlar om 1990-talskrisen och hur miljöfrågan framställdes i samband med den, samt framväxten av idén om det gröna folkhemmet som följde på krisen. Därefter diskuteras trender i hur miljö och välfärd framställts i den svenska politiken under den senaste globala finanskrisen. Till sist binds delarna ihop i ett avsnitt där en diskussion förs om den ekologiska staten som efterföljare eller komplement till välfärdsstaten.

I. Statsministrar under perioden ifråga: Olof Palme (S) 1982-1986, Ingvar Carlsson (S) I986-I99I, Carl Bildt (M i koalition med KD, C, FP) I99I-I994, Ingvar Carlsson (S) 1994-1996, Göran Persson (S) 1996-2006, Fredrik Reinfeldt (M i koalition med KD, C, FP) 2006-20I4, Stefan Löfvén (S i koalition med MP) 20I4-. 


\section{Miljöfrågans framväxt i svensk politisk kontext}

Även om miljöproblem och människans påverkan på naturen har fått ökad uppmärksamhet under senare år är det inget unikt för vår tid utan snarare tätt sammankopplat med samhällsutvecklingen. Miljöfrågor sågs dock tidigare främst som lokala angelägenheter och i relation till mänskligt välbefinnande. Efter andra världskriget uppmärksammades miljöproblem på en internationell nivå genom upptäckten av luftburna utsläpp och kärnkraftens baksidor (Lidskog \& Sundqvist 20II). Genom att etablera miljödepartement, lagar och policyer har miljörelaterade dilemman inkluderats i den politiska agendan i många länder under de senaste decennierna (Christoff 2005). På 1960-talet framträdde miljöfrågor som ett enat politikområde och frågan fick spridning till en större del av befolkningen (Bro 2000). Startpunkten för det internationella miljöarbetet sägs vara 1972 då $\mathrm{FN}$ :s konferens på temat den mänskliga miljön arrangerades för första gången (Lidskog \& Sundqvist 20II). Sverige, som var värd för konferensen, var en av pionjärerna (Meadowcroft 2005; Lidskog \& Elander 20I2) genom att introducera miljöpolitik i stor skala redan under 1960-talet (Duit 2002). Nyckelområdena under de tidiga stadierna av svensk miljöpolitik var vatten- och luftkvalitet liksom etableringen av naturreservat - konsekvenser av den ökade industrialiseringen och urbaniseringen. 1973 påtalade Sveriges kung i sitt årliga öppnande av riksdagen, med anledning av FN:s möte om den mänskliga miljön i Stockholm föregående år, att "Sverige kommer att ta aktiv del i detta arbete" (Prot. 1973/74:2). Detta är bara ett av många exempel som visar att Sverige länge velat profilera sig i miljöfrågor.

På den tiden betraktades dock miljöhänsyn som ett hinder för den viktiga tillväxten. Därmed hade partier som Socialdemokraterna länge en ambivalent inställning till miljöfrågan (Anshelm 1995; Duit 2002). Miljöfrågorna hade en framträdande roll i samhällsdebatten under 1970talet men uppdelningen mellan miljö och tillväxt bibehölls, vilket gjorde att det blev en ideologisk fråga. Enligt mer radikala grupper sågs nolltillväxt och decentraliseringsfrågor, liksom demokrati, som det rätta sättet att möta frågor om ekologi och nå ett lägre energianvändande. Även mer konservativa partier hade en relativt hög miljömedvetenhet (Anshelm 2002). Efter att ha varit en fråga om ideologi kom miljödebatten i slutet 
av 1970-talet att handla mer om tekniska och vetenskapliga lösningar än om utopier. Det fanns i många fall konsensus kring de generella problemformuleringarna, som biologisk mångfald, försurning, växthuseffekten och krympande ozonlager (Anshelm 2002).

I slutet av I980-talet var miljön en av de viktigaste samhällsfrågorna i Sverige, inte minst synlig i de årliga undersökningarna från SOM-institutet. Exempelvis sa rekordmånga, 62 procent, att de ansåg miljön vara en viktig samhällsfråga i SOM-undersökningen 1988 (Bennulf \& Selin 1993). Valet $1988 \mathrm{kom}$ att kallas miljövalet (Bennulf \& Selin 1993) då miljöfrågorna dominerade debatten, vilket också är tydligt i regeringsförklaringen samma år. Det här var även valet då Miljöpartiet de gröna tog plats i riksdagen som första nya parti på 70 år. Från att miljöfrågor tidigare varit uppdelade på olika departement skapades Miljö- och energidepartementet 1987. Utvecklingen hänger väl ihop med internationella händelser, som den av FN släppta "Brundtlandrapporten" som introducerade begreppet hållbar utveckling 1987 (WCED 1987). Begreppet utvecklades sedan än mer under FN:s konferens 1992 i Rio de Janeiro. Den ursprungliga definitionen av begreppet löd: "Hållbar utveckling är utveckling som möter nutida behov utan att kompromissa med kommande generationers förmåga att möta sina egna behov" (WCED 1987, min översättning). Tidigare placerades som vi sett miljö länge i ett motsatsförhållande till tillväxt, men nu presenterades en vision om hur relationen mellan miljö, ekonomisk tillväxt och välfärd kunde förstås på ett annat sätt (Duit 2002; Lidskog \& Sundqvist 20II).

Redan innan begreppet hållbar utveckling formellt lanserats 1987 kan liknande tankegångar hittas, som i statsminister Olof Palmes regeringsförklaring inför riksdagens arbetsår 1985/86. Statsministern knyter samman fattiga och rika delar av världen och talar om kommande generationers rättigheter och om hur "tredje vägens ekonomiska politik", där underskotten i ekonomin minskats men välfärden bibehållits, kan få bukt med miljöproblem:

Den miljöförstörelse som följer i fattigdomens spår hotar kommande generationers försörjningsmöjligheter. Därför måste dialogen mellan Nord och Syd ges ökad vikt [...]. En kraftig ökning av industriinvesteringarna har lagt grunden för fortsatt industriell tillväxt och för en bättre miljö (Palme, Prot. 1985/86:2). 
Redan 1985 fanns således en framåtblickande vision om miljöproblem som något som kommande generationer får tampas med. Dock är det "de" i tredje världen som drabbas, västvärlden är varken inblandad eller drabbad vilket visas eftersom det i regeringsförklaringen presenteras i relation till biståndspolitik. Industriell tillväxt och miljö ställs inte emot varandra, men bättre miljö sägs heller inte främja tillväxt utan är snarare något som möjliggjorts av investeringar inom industrin. Dock ges inga indikationer på den "gröna tillväxt" som introducerades av samma parti ett decennium senare.

Värnet av miljö och natur måste prägla arbetet på alla samhällsområden. En god miljö kan och skall förenas med social välfärd, full sysselsättning och regional balans (Carlsson, Prot. 1987/88:2).

Ovanstående citat framfördes samma år som begreppet hållbar utveckling lanserades, och innefattar begreppets tre dimensioner: det sociala, det ekonomiska och det ekologiska. I slutet av 1980-talet ses miljö som integrerat med andra samhällsområden då "[h]änsynen till miljö och natur måste prägla utvecklingen på alla samhällsområden" (Prot. I988/89:2). Samtidigt ses dock miljöarbete som något som kräver goda finanser, snarare än något som ger det, vilket följande citat antyder. Därmed har inte ekologisk modernisering introducerats i regeringsarbetet ännu.

En radikal miljöpolitik förutsätter en stark ekonomi. Arbetet drivs vidare för att nå överenskommelser över gränserna om minskade luft- och vattenföroreningar och om skydd för jordens klimat [...]. Skiftet mellan 80- och 90-talen bör därför användas för att långsiktigt befästa och stärka det som måste vara grunden även för den framtida utvecklingen: ekonomin, sysselsättningen och välfärden. Därmed skapar vi också handlingsutrymme för den förnyelse och de nya insatser som krävs på en rad viktiga områden: inom miljö- och energipolitiken, i den gemensamma sektorn, i arbetslivet, på skatteområdet och för att stärka vårt samarbete - ekonomiskt, socialt och kulturellt - med andra länder (Carlsson, Prot. 1988/89:2). 


\section{I990-tal. Ekonomisk kris och det gröna folkhemmet}

Som föregående stycke visar var miljöfrågan framträdande åren före den ekonomiska krisen i början av 1990-talet. Lundqvist (2000) målar upp en bild där svensk miljöpolicy höll en god standard och präglades av långsiktiga mål och ett brett angreppssätt fram till i990-talet. Liksom inom andra politikområden kännetecknades miljöområdet då av konsensus och samarbete. Detta förändrades dock av den ekonomiska krisen som kulminerade 1992, men även av att frågan ändrade karaktär och kom att handla om klimatförändringar och hållbarhet (Lundqvist 2000, s. 22).

I takt med att den finansiella krisen eskalerade minskade allmänhetens intresse för miljöfrågor till förmån för sysselsättning och Sveriges ekonomi, menar Martin Bennulf och Henrik Selin (1993). Io respektive 7 procent av befolkningen ansåg att Sveriges ekonomi och sysselsättningen var viktiga frågor 1988, medan 40 respektive 49 procent tyckte det I992. Miljö gick i motsatt riktning - från 62 till i9 procent under samma år. Men även om fokus på miljö förändrades bland många medborgare upptog miljöfrågan fortsatt stort utrymme i regeringsförklaringarna under 1990-talets första år, vilket tyder på att diskursen där miljö har en stark ställning i politiken låg kvar trots den sviktande opinionen. En av de fyra huvudsakliga uppgifter som nytillträdda statsminister Carl Bildt tecknade för sin koalitionsregering I99I var att "forma en långsiktig och hållbar utveckling mot ett samhälle med frisk luft och rent vatten, med levande sjöar och skogar” (Prot. 1991/92:6). I citatet nämns alltså begreppet hållbar utveckling, som introducerades för den stora publiken fyra år tidigare. Detta uttrycks dock som ett nationellt mål då det inbegriper sjöar och skogar snarare än klimat, och hållbar utveckling sågs som något endast förknippat med miljö snarare än en övergripande målsättning för alla politikområden.

I I990-talets början talar statsminister Bildt ofta om åtgärder för att öka tillväxten. En sanering av ekonomin och sänkningar av vissa skatter, däribland på energiområdet (Prot. 199I/92:6) beskrevs som ett måste för att bekämpa den pågående finansiella krisen. Tillväxt sågs under 1990talet som en nödvändighet för att skapa och bibehålla välfärden. En god 
miljö framställs som en framtidsutmaning som ligger i allas intresse och som en rättighet i regeringsförklaringen 199I/92. Det är den "ekonomiska och den tekniska utvecklingen [som] skapar unikt goda möjligheter för omställningen till mindre resurskrävande och miljöbelastande produktions-, energi- och transportsystem.” Därmed ses den ekonomiska nedgången som en möjlighet till omställning. Miljö och ekonomi är tydligt sammankopplade såtillvida att teknisk utveckling anses främja miljövänliga produkter och inte tvärtom. De gröna näringarna anses alltså inte bidra till utveckling och tillväxt. Miljömål och styrmedel samt lagstiftning ses som viktiga insatser. Här knyts ekonomi och ekologi samman, men miljö ses fortfarande som en hindrande faktor för tillväxt. Året efter sker dock en förändring av hur miljöfrågor positioneras mot andra samhällssektorer då statsminister Bildt deklarerar att "[d]et finns dock tecken på att miljö inte anses hindra tillväxt" (Prot. 1992/93:2).

Miljötänkandet anses härmed inte självklart stå i motsättning till tillväxt, utan kan snarare kopplas till marknadsutveckling och sysselsättning. Den I januari 1995 gick Sverige med i Europeiska gemenskapen, EG, som senare skulle bli EU. Åren innan inträdet talas det mycket i regeringsförklaringarna om vilka fördelar Sverige skulle åtnjuta som medlemmar. Medlemskapet presenterades som en framtida nödvändighet som skulle motverka arbetslöshet och krig och inte minst vara till gagn för miljöarbetet.

I 1994/95 års regeringsförklaring, efter maktskiftet i Rosenbad, sägs att "den grundläggande uppgiften för regering och riksdag är att åstadkomma en social och ekonomisk modernisering av Sverige" (Prot. I994/95:2). Välfärd är en av de viktigaste frågorna för nytillträdda statsminister Ingvar Carlsson och välfärden kopplas samman med demokrati, ekonomiska och sociala rättigheter, familjepolitik, utbildning, sjukvård och omsorg - inte miljö. Bara ett år senare framhävs dock behovet av en modernisering av den svenska politiken i regeringsförklaringen. Ett av stegen är "[...] överlevnaden och arvet till kommande generationer; att låta hänsynen till miljön genomsyra såväl politiska beslut som våra personliga handlingar.” (Prot. 1995/96:2.) Därmed lägger Carlsson ansvar på politiken liksom enskilda individer, och miljön binds samman med andra delar av samhället. Behovet av en ökad tillväxt knyts till en aktiv 
miljöpolitik, men även välfärd ses som en av nycklarna till ekonomisk tillväxt.

En ökad miljömedvetenhet har blivit en viktig drivkraft för en tillväxt som inte tär på våra naturtillgångar. Miljöanpassade produkter och processer efterfrågas i ökad utsträckning och är en allt viktigare konkurrensfaktor för företagen. Sverige har goda förutsättningar att åstadkomma en grön tillväxt (Carlsson, Prot. 1995/96:2).

Vid nästa regeringsförklaring har statsminister Göran Persson hunnit lansera det gröna folkhemmet. Förverkligandet av "det ekologiskt hållbara industrisamhället" fick stort fokus i mitten av I990-talet. Efter att den värsta krisen bedarrat kom tron på att grön teknologi och ett miljövänligt tänkande skulle kunna främja tillväxten och leda Sverige ut ur den ekonomiska lågkonjunkturen, inspirerat av tanken om hållbar utveckling. Det var i skuggan av detta som det gröna folkhemmet formulerades. I det gröna folkhemmet skulle inte bara ekologiska men också sociala och ekonomiska faktorer vägas samman och grön tillväxt skulle därmed gynna allt och alla. Hållbar utveckling ansågs vara ett sätt för Sverige att:

[...] vara en pådrivande internationell kraft och ett föregångsland i strävan att skapa en ekologiskt hållbar utveckling. Välståndet skall byggas på en effektivare användning av naturresurserna - energi, vatten och råvaror (Persson, Prot. 1996/97:2).

Även om det fortfarande talas om en "ekologisk" hållbar utveckling skymtas ändå en sammankoppling av miljöfrågan, andra samhällssektorer och välfärd, och också en koppling till framtiden och kommande generationer. 1998/99 uttrycks omställningen till hållbar utveckling som en av fyra strategier "för att stärka Sveriges konkurrenskraft och utvecklingsmöjligheter" (Prot. 1998/99:2). Angreppssättet gick här över till det som kallas för ekologisk modernisering, ett begrepp som enligt Maarten A. Hajer (1995) är nära besläktat med hållbar utveckling. Kärnan i ekologisk modernisering är att miljöskydd har omvandlats till ett plussummespel (Hajer 1995; Lundqvist 2000) där industrin kan utveckla grön teknologi på ett vinstgivande sätt och politiker kan tala sig varma för grön tillväxt. 
Enligt Benjamin Vail (2008, s. 92) är den huvudsakliga målsättningen för den ekologiska moderniseringsteorin "att förklara förändringar i relationen mellan sociala institutioner - det vill säga staten, marknadsaktörer och civilsamhället - i relation till miljön” (min översättning), där statens roll förändras sedan intresseorganisationer och internationella institutioner får ökat inflytande och företag tar ett större ekologiskt ansvar då miljöintressen blivit en institutionaliserad del av marknaden (Vail 2008; Mol \& Sonnenfeld 2000; Mol 1999). Svensk miljöpolitik kan sägas vara genomsyrad av ekologisk modernisering sedan slutet av I990-talet, även om statens roll har varit fortsatt framträdande i motsats till den decentraliserade roll som den ekologiska moderniseringsteorin förutspått (Vail 2008; Mol \& Sonnenfeld 2000; Mol 1999).

Skapandet av det gröna folkhemmet jämförs i Perssons (2007) självbiografi med övergången till en välfärdsstat under I950-talet. Idén var, just som ett halvt sekel tidigare, att lösa kriser genom investeringar och nya institutionella arrangemang. Lokala investeringsprogram liksom senare klimatinvesteringsprogram, var några av de åtgärder som förordades. Det gröna folkhemmet var tänkt att bli Socialdemokraternas nya ideologiska plattform sedan det ursprungliga konceptet legat i träda under några decennier. Folkhemmet introducerades 1928 av Per Albin Hansson, då ledare för Socialdemokraterna, och visade sig vara essentiellt för partiet och för skapandet av det svenska välfärdssystemet med sin inriktning på jämlikhet, generell distribution av välfärdsservice och avskaffande av klasskillnader. Folkhemmet ledde slutligen till den välutvecklade offentliga sektor med ett generöst socialförsäkringssystem, barnbidrag, pensioner, vård och utbildning som är karaktäristiskt för idealiserade beskrivningar av den svenska välfärdsstaten. När Göran Persson återuppväckte begreppet och lade till "det gröna", var det med intentionen att inkludera ansvar för, och solidaritet med, inte bara nutida medborgare utan även framtida generationer och andra delar av världen. Vidare skulle det gröna folkhemmet sätta Sverige på kartan som ett internationellt föregångsland inom grön utveckling (Persson 2007; Anshelm 1995, 2002).

Från att relationen mellan ekologisk hållbarhet och tillväxt kännetecknades som ett nollsummespel, eller till och med ett minussummespel på 1970-talet, sågs det på I990-talet som ett plussummespel. Stefan 
Edman (1998, s. 217-2I8), rådgivare åt statsminister Persson: "omställningen till hållbarhet utgör därtill den troligen starkaste motorn för tillväxt, sysselsättning och tryggare välfärd här hemma”. Oavsett om skapandet av det gröna folkhemmet var strategiskt eller ideologiskt motiverat från Socialdemokraternas håll tjänade det ändå syftet att försöka förena näringsliv, fackförbund och miljörörelsen, samt att skapa en koalition med Centerpartiet (Lundqvist 2000). Inte långt efter att det gröna folkhemmet lanserades samlades även alla lagar som berörde miljöfrågor under en samlad stadga, miljöbalken, vilket också underlättade den lagtekniska delen av frågan. Eftersom Sverige genomgick en ekonomisk kris med negativ tillväxt under flera år, förväntades det gröna folkhemmet skapa arbetstillfällen och sålunda även välfärd. Till skillnad från de diskussioner som pågick på 1970-talet var socialdemokratins ledning nu övertygad om att ingen konflikt mellan tillväxt och miljöskydd rådde, snarare tvärtom. Skyddandet av miljön var inte nog i sig självt, utan det var dess roll som garant för välfärd och tillväxt som var viktig, vilket kan uttryckas som ett antropocentriskt synsätt.

Kritik förekom dock. De konservativa och liberala menade, trots att också de förespråkade gröna investeringar, att inställningen var för statscentrerad. De menade att marknaden kunde hantera frågan utan att staten lade sig i och att mer ansvar borde ligga på individen. Miljöpartiet och flera miljöorganisationer var tvärtom kritiska till själva sammanslagningen av miljö och tillväxt. De förespråkade i stället inte bara tekniska innovationer utan även förändrade livsmönster och vanor (Anshelm 2002). Jonas Anshelm (2002) menar därför att tre förståelser av miljöpolitikens inriktning och den ekologiska moderniseringens roll (och utformning i densamma) existerade i Sverige under det sena I990talet. En första i vilken staten hade en framträdande roll genom politisk styrning av produktion och konsumtion mot hållbar utveckling, en andra där förtroendet sattes till marknadsmekanismer och en tredje som menade att det fanns en motsättning mellan tillväxt och miljö, och som varnade för att betro marknaden och teknologiska innovationer i för hög utsträckning, och som därmed motsatte sig en av grundbultarna i den ekologiska moderniseringsteorin. 


\section{0-tal. Nya frågor, nya kriser}

Socialdemokraterna behöll sin satsning på det gröna folkhemmet några år in på 2000-talet:

Herr talman! Jag vill att vi bygger det gröna folkhemmet.

Miljöpolitiken rör på djupet frågor om ansvar och moral. Det handlar om framtiden, om våra barn och deras barn och nya generationers livsvillkor. Sverige ska fortsätta vara ett föregångsland i omställningen till hållbar utveckling (Persson, Prot. 2002/03:2).

Den första nationella strategin för hållbar utveckling (Skr. 200I/o2:172) lanserades 2002, samma år som ovanstående citat framfördes. Det var den socialdemokratiska regeringen under Göran Persson som lanserade strategin, vilket är tydligt eftersom innehållet överensstämmer väl med det gröna folkhemmet. Sedan I januari 2003 är det ett uttalat mål att den svenska offentliga sektorn ska förespråka hållbar utveckling för nutida och framtida generationer (Skr. 2005/06:107, s. 6), hållbar utveckling är därför att betrakta som en övergripande politisk målsättning. Strategin, som reviderats vid två tillfällen sedan dess (2004 och 2006), är tydlig med att hållbar utveckling har tre dimensioner: den ekologiska, sociala och ekonomiska. Tre parametrar identifieras som övergripande: I) Sverige kan bara nå hållbar utveckling genom regionalt och internationellt samarbete, 2) hållbar utveckling måste inkluderas i alla politikområden, 3) för att säkerställa långsiktigt skyddande av resurser krävs nationella interventioner.

Diskursen om hållbar utveckling finns således kvar, men miljöfrågan ändrar fokus och handlar alltmer om klimatet. Klimatförändringarna är en alltigenom global fråga, och berör förändringar på en lång tidsskala, vilket gör dess roll i nationell politik extra intressant. Även om oron för ett förändrat klimat dök upp redan vid slutet av 1980-talet har klimatfrågan fătt alltmer uppmärksamhet sedan mitten av 2000-talet, nationellt liksom internationellt, där organ som FN och EU har tagit upp frågan på agendan. En av orsakerna till det ökade intresset för klimatfrågan i regeringsförklaringarna är Sveriges ordförandeskap i EU 2009; landet förväntades ha en hög profil under FN-mötet om klimatet samma år i Köpenhamn. Det ökade fokuset innebar också att andra miljöfrågor 
försvann ur regeringsförklaringarna. Den förändrade agendan vittnar enligt While med flera (20I0, s. 76) om "en ny insikt om antropogen klimatförändring och dess socioekonomiska konsekvenser, liksom om bredare ekonomiska och politiska incitament för statliga strategier för koldioxidhantering" (min översättning). Klimatförändringar och energifrågor hamnar därmed alltmer i världspolitikens fokus generellt, och i den europeiska politiken specifikt, vilket har följdverkningar på nationell och lokal nivå. I klimatpolitiken ryms både tillväxt och hållbar utveckling och Sverige anser sig kunna trygga sin energitillförsel utan att riskera tillväxten. I nedanstående citat visas inte bara på sammansmältningen av energi- och miljöfrågan (via klimatdebatten) utan också på att den borgerliga regeringen vid makten vid tillfället såg frågan i ett längre tidsperspektiv och att den skulle lösas med hjälp av marknaden. Något motsägelsefullt delades dock samtidigt miljö- och energifrågorna upp i varsitt departement, Miljödepartementet och Näringsdepartementet. ${ }^{2}$

Energifrågan hör intimt samman med klimatfrågan [...]. Regeringen avser därför att föra samtal med riksdagens partier i klimatberedningen om förutsättningarna för en bred, långsiktig, modern och marknadsekonomiskt orienterad energipolitik (Reinfeldt, Prot. 2007/08:2).

I 2006 års regeringsförklaring är det tydligt att klimatet och Östersjön är i fokus. Nytillträdda moderate statsminister Fredrik Reinfeldt:

Viktiga steg ska tas för att möta framtidens miljöproblem. Klimatfrågan är en ödesfråga för Sverige och för världen. Regeringen ska lägga stor kraft på att säkerställa Östersjön och Västerhavet som levande hav. Miljöfrågorna är avgörande för utvecklingskraften för Sverige (Prot. 2006/07:6).

Citatet visar vidare att miljö ses som en garant för Sveriges förmåga att utvecklas och för tillväxt, inte tvärtom som det framställts tidigare. Globalisering framställs som en framtida utmaning då den ökar konkurrensen. Samtidigt har Sverige mycket att vinna på en global marknad, och Sverige kan genom sin utrikespolitik påverka i riktning mot demokrati (se även Edman 1998). I följande citat av den föregående socialdemo-

2. Sedan valet 2014 är de återigen samlade under Miljö- och energidepartementet (Regeringen 2015). 
kratiska statsministern binds klimatfrågan samman med det landskap som omger oss i vardagen, det vaga hotet från klimatförändringarna med naturkatastrofer i nutid.

\begin{abstract}
Alla är vi starkt präglade av den natur- och kulturmiljö där vi har vuxit upp och levt våra liv. Därför skräms vi i dag av klimatförändringarna. Jordens medeltemperatur stiger, mest närmast polerna. Det svenska landskapet hotas av fler stormar, översvämningar och längre perioder av torka. Kampen mot miljöförstöringen ställs i ett helt nytt ljus. Omdaningen av samhället till en hållbar tillväxt måste påskyndas. Omställningen rymmer enorma möjligheter för teknisk utveckling, forskning och innovationer, för tillväxt och nya jobb i Sverige - men också möjligheter att bidra till global rättvisa (Persson, Prot. 2005/06:2).
\end{abstract}

Statsministern drar slutsatsen att en hållbar tillväxt, snarare än en minskad tillväxt, är nyckeln för att komma till rätta med problemen. Att ställa om samhället i en mer hållbar riktning gynnar inte bara miljön utan också industrin, forskningen och utvecklingen på det tekniska området, vilket visar på att intresset för frågan inte bara handlar om värnandet av miljön. Det är en antropocentrisk syn på miljön och naturen som något existerarande för det mänskliga samhällets skull.

Hållbar utveckling gör att miljöfrågan klamrar sig fast i den politiska retoriken också under det sena 2000-talet, vilket är tydligt i ovanstående citat även om intresset för frågan i den allmänna opinionen föga förvånande dalade under finanskrisen (Harring m.fl. 20II; Jormfeldt \& Sjöstrand 20I4). Till skillnad från under 90-talskrisen beskriver statsministern att Sverige klarade sig jämförelsevis bra i krisen. Enligt den moderata statsministern lyckas Sverige skapa minskade utsläpp samtidigt som ekonomin växer och är därmed ett föregångsland, både ekologiskt och ekonomiskt, i tider av global ekonomisk oro. Sverige hade lärt sig vikten av att ha en budget i balans och en ansvarsfull ekonomisk politik, hette det (Prot. 2008/09:2). Arbetslinjen var den borgerliga alliansens främsta käpphäst; en låg arbetslöshet skulle inte bara ge bra statsfinanser utan även välfärd då arbete innebär skatteintäkter, nödvändiga för att bygga välfärden. Finanskrisen var ett bevis på att jobben var rätt prioritering, enligt Reinfeldt (Prot. 2009/IO:2). Den finansiella krisen skulle motarbetas med en finanspolitik som gav långsiktiga förutsättningar för jobb och tillväxt, och miljö sågs i det här läget (2013) inte 
som en lösning på krisen. När statsminister Reinfeldt listar de områden som Sverige under finanskrisen, tack vare sina goda finanser, har kunnat investera i snarare än att skära ned på, är det framför allt välfärd, sysselsättning och utbildning. Miljö nämns inte i de sammanhangen. Kanske anses ämnet inte höra dit, eller så tas dylika intressen för självklara, eller så är det inte ett lika prioriterat område som det framställs i andra delar av regeringsförklaringen.

Men även om Sverige klarat sig bra i den senaste finanskrisen visar krisen enligt Reinfeldt hur sammanlänkat Sverige är med resten av världen, inte minst Europa. Samma sak sägs gälla på miljöområdet:

Även betydande investeringar i klimat och energi sker i framtidspaketet. Vi ska ta vår del av ansvaret för de globala klimatförändringarna och göra Sverige framgångsrikt $\mathrm{i}$ en global klimateffektiv ekonomi - detta samtidigt som vi tryggar vår energiförsörjning och ökar vår andel av förnybar energi. Vi möter klimathotet med en politik där tillväxt och hållbar utveckling går hand $\mathrm{i}$ hand och med en vilja att visa ledarskap, men också med en insikt om att enbart nationella insatser är ett otillräckligt svar på ett globalt problem (Reinfeldt, Prot. 2008/09:2).

Som syns i ovanstående citat anses också klimatfrågan till syvende och sist vara en global fråga. Att det internationella fokuset på miljö- och klimatfrågan i dag är ett tydligt incitament för att arbeta med frågan för både Socialdemokraterna och Moderaterna framgår i deras respektive framtidsvisioner där det även understryks att Sverige redan har ett vetenskapligt och tekniskt försprång och bör sträva efter att behålla ledartröjan för att på så sätt främja export och arbetstillfällen i dessa branscher (Moderaterna 2013; Socialdemokraterna 2013). EU:s betydelse för ett framgångsrikt miljöarbete understryks av majoritet liksom opposition. I sitt anförande 2010 nämner Reinfeldt energi- och klimatfrågan före andra miljöfrågor, och i en levande landsbygdskontext, vilket innebär en delvis ny inriktning på den gröna politiken:

Med en ambitiös energi- och klimatpolitik skapas grund för investeringar och företagande på landsbygden. De gröna näringarna är betydelsefulla (Prot. 2OIO/II:2).

Uttalandet rimmar väl med inriktningen på det internationella miljöarbetet. År 2012 uppmärksammades 40-årsjubileet av FN-mötet om mil- 
jön i Stockholm med konferensen Stockholm +40 - Partnership Forum for Sustainable Development (Regeringen 20I3a). Det övergripande temat på konferensen var hållbara innovationer, hållbar produktion och en hållbar livsstil. Detta speglar den allmänna politiska trenden att lägga fokus på industrin, marknaden och individen snarare än på politiska verktyg och staten som aktör. Tillväxt genom marknadsinriktad miljöpolitik skapar behov av konkurrens i energimarknaden. Detta kommer enligt Moderaterna (2013) att innebära billig energi vilket gör Sverige konkurrenskraftigt. Samtidigt menar moderater, liksom socialdemokrater (något motsägelsefullt), att staten fortfarande har en viktig roll att spela. I nedanstående citat menar Moderaterna att statliga insatser krävs för att energiproduktionen inte endast ska vara billig utan även miljövänlig:

Staten har en roll i att stödja framväxten av ny energiproduktion genom att bidra till finansieringen av forskning och utveckling samt underlätta miljöriktiga val för konsumenterna (Moderaterna 20I3, s. 3I).

Därmed har nationalstaten en viktig roll som garant för att andra värden än ekonomiska prioriteras. Att staten behövs för att trygga miljövänlighet kan dock uppfattas som en motsägelse till tron på att en miljövänlig inriktning ger högre vinster för företagen och att de därmed, på grund av marknadskrafterna, borde genomföra en grön omställning utan statliga direktiv. Citatet gör också gällande att energianvändningen inte bör begränsas, utan göras mer effektiv och grön. Energitillförseln ses inte som ett nollsummespel utan som ett ymnighetshorn, för att låna Alf Hornborgs (2002) uttryck.

Sammanfattningsvis kan följande utdrag från den överenskommelse som partiledarna för alliansen, det vill säga den borgerliga regeringen, gjorde 2009 (Proposition 2008/09:I62) om energi- och klimatpolitiken användas för att exemplifiera den svenska miljöpolitiken under de senaste åren. Citatet visar på de starka banden till EU och den globala sfären, på att miljömedvetenhet och övergången till förnybara resurser inte är nog i sig själv utan måste ge ekonomisk tillväxt, men också på tron på de tre benen i hållbar utveckling - det sociala, ekologiska och ekonomiska: 
ARKIV | NR 6

Den svenska energipolitiken - och därmed även basen för klimatpolitiken - ska bygga på samma tre grundpelare som energisamarbetet i EU. Politiken syftar alltså till att förena: ekologisk hållbarhet, konkurrenskraft, försörjningstrygghet (Proposition 2008/09:I62, s. II).

\section{Miljö och tillväxt - relationen som gick från minus till plus}

I min analys utkristalliseras en stegvis utveckling av relationerna mellan miljö, välfärd och tillväxt i samband med 1990- och 2000-talskriserna. Miljöintresset var rekordstort i slutet av 1980-talet, innan den svenska ekonomiska krisen. Fokus på miljö ansågs dock inte skapa tillväxt och var därför sekundär efter välfärdsfrågor. 1990-talets kris dämpade intresset för miljöfrågan hos allmänheten men frågan klamrade sig fast i den politiska retoriken. Begreppet hållbar utveckling började få fotfäste. Tack vare diskursen om hållbar utveckling, som blev en sorts återhämtningsplan efter krisen, framställdes grön tillväxt som framtidens melodi. Miljö sågs inte som en motsättning till tillväxt utan tvärtom som en motor för densamma och för välfärden. Socialdemokraterna lanserade det gröna folkhemmet som ett sätt att länka samman miljö och välfärd. Mellan de båda finanskriserna gick Sverige med i EU (dåvarande EG). Det har påverkat Sveriges sätt att arbeta inte bara med miljöfrågor utan även med välfärdsfrågor. Även om miljö länge framhävts som ett internationellt politikområde, har bundenheten till EU:s mål och ambitionen att Sverige ska vara ledande på området i unionen blivit tydligare sedan slutet av 1990-talet.

Klimatfrågan har kommit att bli den främsta miljöfrågan, inte bara i Sverige utan även internationellt. Då Sverige vill behålla ledartröjan i miljöarbetet kan frågan inte negligeras ens under den globala finanskrisen. I stället framhålls att Sverige trots krisen lyckas minska utsläpp och främja tillväxt, även om motsvarande framgångar inte kan sägas gälla för välfärden. Miljön har på ett sätt släppts in i de fina salongerna. Det går inte att inte tala om detta som politiskt parti eller statsminister i dag. Men trots diskursen om hållbar utveckling litar man inte, i tider av ekonomisk oro, på grön tillväxt eller omställningar för att skapa tillväxt. De kan samvariera, men inte fullt ut leda till tillväxt. Miljön nämns fortfa- 
rande i samma sammanhang som välfärden, men den nämns inte som en lösning på samma vis som i talet om det gröna folkhemmet. Miljö framställs som ett högt prioriterat framtida politikområde. På längre sikt menar både moderater och socialdemokrater att miljöfokus kommer att leda till inte bara en bättre värld utan även till tillväxt. Men vad som följer i spåren av den senaste finanskrisen återstår fortfarande att se. Kan maktskiftet 20I4, trots att inga sådana tendenser är tydliga i dagsläget, förnya visionen om ett "grönt folkhem" där miljömedvetenhet ska bygga upp Sverige och Europa efter krisen? Baserat på att miljöfrågan intog en blygsam position i senaste valrörelsen (se t.ex. Rockström 20I4), och på att Miljöpartiet kritiserades för att ha lämnat sin huvudfråga miljön (se t.ex. Kärman 20I4; Karlsson 20I5), ser det i nuläget inte troligt ut. Diskursen i vilken miljöfrågan ses som en motor för tillväxt återfinns i den senaste regeringsförklaringen (Prot. 2014/15:6), dock utan att gröna satsningar lanseras som ett tydligt alternativ för en förbättrad ekonomi eller en ideologisk inriktning för regeringspartierna.

Som jag påpekade $\mathrm{i}$ artikelns inledande stycke var miljöfrågan fram till 1970-talet ideologisk för att därefter vetenskapliggöras och teknokratiseras. Genom att kombinera välfärd och miljö, och göra det gröna folkhemmet till socialdemokratins nya kärnfråga blev miljöfrågan återigen ideologisk i mitten av 1990-talet (Anshelm 2002). Det gröna folkhemmet användes som synonym till hållbar utveckling genom att det, liksom hållbar utveckling i den så kallade Brundtlandrapporten (WCED 1987), omtalas i generationstermer. Samtidigt ville statsminister Persson få det gröna tankesättet att framstå som något moraliskt riktigt, något som måste tas itu med och som det är Sveriges ansvar att gå i bräschen för. I dag har miljöfrågan återigen blivit avideologiserad. Samtidigt som påtryckningarna för att minska koldioxidutsläppen i världen för att bromsa klimatförändringarna är större än någonsin är det få som talar om att bromsa tillväxten. Varken den borgerliga svenska regeringen 2006-20I4 eller dess opposition talade om ett lågenergisamhälle eller att neddragningar i levnadsstandard kan vara aktuella i framtiden. Den borgerliga regeringen menade att Sverige har bevisat att minskade utsläpp av växthusgaser kan kombineras med ekonomisk tillväxt och att "klimatutmaningen ska användas som en ekonomisk hävstång för jobb, export och tillväxt" 
(Regeringen 2013b). Citatet är ett exempel på en officiell syn på miljöproblem där de ses som fördelar snarare än hinder för tillväxt, och ett uttryck för ekologisk modernisering (Lidskog \& Sundqvist 20II). Hållbar utveckling har letat sig in i politiska program och strategier på lokal, nationell och internationell nivå och omhuldas av både den politiska vänstern och högern. Med lanseringen av de "Nya Moderaterna" 2005 positionerade sig det tidigare så konservativa Moderata samlingspartiet mer mot den politiska mitten och öppnade då upp sin politik för mer välfärdsorienterade frågor, så som sysselsättning, skola och omsorg. På samma sätt har de anammat målet om en hållbar, grön tillväxt.

Som synes har hållbar utveckling spelat en viktig roll i formandet av svensk miljöpolitik under de senaste årtiondena och lett till att miljö blivit en alltmer etablerad politisk fråga. Lanseringen och den politiska implementeringen av "hållbar utveckling" har säkerligen också påverkat utvecklingen och förståelsen för den komplexa relationen mellan sociala, ekonomiska och ekologiska aspekter (Jormfeldt \& Sjöstrand 20I4). I början av 200o-talet framhölls miljöteknik fortsatt som ett område där Sverige ligger i framkant och som leder till exportintäkter. Därmed byggdes bilden av den gröna tillväxten på:

Världsmarknaden för miljöteknik växer snabbt. Vinstmöjligheterna är mångdubbla. Ökade satsningar på teknikutveckling och teknologiutbyte kan både lösa globala miljöproblem, främja svensk industri och driva på tillväxten till förmån för välfärd och rättvisa. Fortfarande pågår en ohållbar utveckling. Den går att vända. Det går att bygga ett grönt folkhem som går före. Men det kräver att alla är med och delar ansvaret (Persson, Prot. 2002/03:2).

Ovan talar statsminister Persson inte bara om att tillväxt, miljömedvetenhet och även välfärd går att sammanföra, utan han för också in en individuell aspekt - alla medborgare hålls medansvariga för att det ska lyckas. Tanken om grön tillväxt och ekologisk modernisering var gemensam för Perssons socialdemokratiska och den efterföljande borgerliga regeringen. Miljöfrågan handlar under andra halvan av oo-talet till stor del om kostnadsläge, priser, konkurrens, beskattning och lagstiftning. "[M]iljö- och energibeskattningen ska utformas så att det lönar sig att ta miljöansvar" heter det, samtidigt som "företag och konsumenter ska 
kunna lita på att det finns energi till internationellt konkurrenskraftiga priser i framtiden" (Prot. 2006/07:6), vilket visar att det är tillväxt och ekonomi som går först.

Hållbar utveckling har "gjort en triumfmarsch, inte bara in i parlamentariska byggnader och på miljöorganisationernas huvudkontor utan också in i de transnationella företagens styrelserum, liksom bland miljöforskare" (Lidskog \& Elander 20I2, min översättning), men kan kritiseras för att vara vagt och godtyckligt. Kritiker menar att dess karaktär gör det acceptabelt för alla och därför tandlöst (Anshelm 2000; Duit 2002; Hassler 2005), och att det upprätthåller utveckling snarare än att fokusera på orsakerna till miljöproblemen (Hajer 1995). Hållbar utveckling uppkom som en holistisk syn där natur, ekonomi och samhälle ses som en helhet, men den nuvarande betydelsen kan kritiseras för att styras av nyliberala strategier där miljöskydd blir sekundärt efter ekonomisk konkurrenskraft. Exempelvis bygger implementeringen av miljöpolicyer i EU främst på marknadsåtgärder såsom koldioxidhandel (se t.ex. Sommestad 20I2). Trots kritik visar dock implementeringen av hållbar utveckling hur miljöfrågor kan knytas till socialpolitik och ekonomisk utveckling, och har gjort att miljöfrågorna har fått en helt annan position i det svenska välfärdsbygget. Men diskussionen om hållbar utveckling har även präglat samhällsdebatten i stort, och gjort att teoretiska begrepp såsom ekologisk modernisering kan appliceras på hur stater ser grön tillväxt som en win-win-situation för miljön och ekonomin (Hajer I995; Medina 2013; Lundqvist 2000). Eftersom begreppet inte utesluter välfärd och tillväxt kan politiker och myndigheter på lokal liksom nationell och överstatlig nivå upprepa "hållbar utveckling" likt ett mantra. Samtidigt innebär detta en extra dimension för myndighetsutövare att ta hänsyn till, vilket kan ha konsekvenser för andra politikområden (Edberg \& Fransson [kommande]).

\section{Från nationell välfärdsstat till global ekostat?}

I900-talet var välfärdsstatens århundrade, och vad det verkar lever den kvar även under det innevarande seklet. Välfärdsstaten har dock utvecklats och uppfattningen av vad den bör innehålla samt dess roll har för- 
ändrats under tidens gång. Därmed kan nya områden anses tillhöra välfärdsstatens intresseområden i olika tidsepoker. Men naturligtvis också i olika rumsliga kontexter. Vi ställs inför nya utmaningar då faror tar en global och på många sätt vag form genom svårigheten att avgränsa dem spatialt, temporalt eller socialt. Miljöproblem såsom klimatförändringar och försurning sträcker sig över nationsgränser, påverkar alla samhällsklasser och har långtgående konsekvenser som är svåra att förutse. Det gör att frågorna måste adresseras internationellt. Klimatkrisen (även om den inte benämns så i regeringsförklaringarna) och finanskrisen sägs visa på samma sak: att olika delar av världen är förbundna med varandra och att nationalstaten inte kan lösa alla utmaningar (Prot. 2009/Io:2). EU har, i vår del av världen, kommit att bli en viktig aktör, och dess medlemmar måste anpassa sin politik efter unionens mål. Samtidigt framstår det också som viktigt att vara ledande inom olika områden, som att Sverige gärna utger sig för att ligga i framkant vad gäller miljöarbetet.

Om hållbar utveckling kan sägas förena miljö och tillväxt, och om överstatliga aktörer får ökat inflytande, kan vi då tala om en ny sorts välfärdsstat? Sandstedt (200I) menar att inkluderingen av ekologiska parametrar i bostadspolitiken visar att dagens välfärdsstat inte bara inkluderar sociala faktorer utan att vi i dag bör prata om en hållbar snarare än en social välfärd. Inkluderingen av hållbar utveckling i den svenska politiken förändrar relationen mellan stat och medborgare då "alla politikområden dras in i den nya diskursen" (Sandstedt 200I, s. 329). Genom att inkludera miljöfrågan i andra politikområden, så som bostadspolitiken, förenas det lokala perspektivet (boendemiljön) med det globala (klimat, utsläpp, etc.). De risker som kan drabba medborgare uppkommer inte bara inom nationens gränser; välfärden i Sverige är beroende av hur situationen ser ut på andra ställen på jorden. Dessutom förenas nutid med framtid då planeringen måste ta med framtida generationers behov i beräkningen (Sandstedt 200I).

Miljöproblem, och då speciellt gränsöverskridande och svårupptäckta sådana såsom klimatförändringar, är komplexa frågor på grund av sin globala och i tiden långt utsträckta natur. Frågan angår alla men eftersom det är omöjligt för enskilda aktörer att säkerställa att andra aktörer kommer att agera finns risken att ingen agerar. Det enda sättet att borga för att 
dylika problem hanteras är att det finns fungerande institutioner (lokala, nationella och överstatliga) som samlar aktörerna (Duit 2002). Även om det kan verka som att staten har spelat ut sin roll som den viktigaste aktören på grund av många samhällsfrågors globala karaktär finns det tecken som tyder på motsatsen. Det handlar delvis om hur vi uppfattar staten. I artikelns inledning skrev jag om hur staten har en dubbell roll som välfärdsgivare eftersom den ska fungera både som möjliggörare för kapitalackumulation och ekonomisk tillväxt, och samtidigt skydda medborgare och natur från skadliga ekologiska och sociala konsekvenser av samma tillväxt (Eckersley 2004; Barry \& Eckersley 2005). Samma dubbla roll kan också påvisas i relationen mellan välfärdsstaten och miljön då staten, å ena sidan, är ansvarig för miljöskydd men, å andra sidan, orsakar miljöförstöring genom den ständiga tillväxt som staten traditionellt menar att den behöver för att kunna generera välfärd. I det som Robyn Eckersley (2004) kallar "den gröna staten" har staten dock en helt annan roll i beskyddandet av både mänskliga och icke-mänskliga delar av samhället. Den normativa idealtyp som Eckersley (2004, s. 2) målar upp är inte bara en liberal demokratisk stat med ett starkt miljöengagemang, utan "en demokratisk stat vars ideal om reglering och demokratiska procedurer är influerade av ekologisk demokrati snarare än liberal demokrati. En dylik stat kan förstås som en postliberal stat i den mån den utgår ifrån en inneboende (ekologisk) kritik, snarare än ett öppet avfärdande av liberal demokrati” (min översättning). Staten kan, och måste, således ses som en fortsatt viktig aktör i miljöfrågan (Eckersley 2004; Meadowcroft 2005), vilket vi kan se att den har i det svenska fallet (om än förändrad).

Kommer välfärdsstaten så som vi känner den efterföljas av "en stat som låter ekologiska överväganden bli kärnan i sin verksamhet" (Meadowcroft 2005, s. 3, min översättning)? Möjligen saknas en tydlig brytpunkt mellan dem då det enligt James Meadowcroft (2005) finns ett antal likheter mellan välfärdsstaten och vad han kallar "ekostaten" (ecostate). Den ekologiska staten inkluderar fler intresseområden i statens uppdrag än dess föregångare, vilket också kan sägas om den traditionella välfärdsstaten, när den växte fram. Vidare är eko- och välfärdsstaten båda ett gensvar på att marknaden eller frivilliga aktörer, så som familjen, inte uppfattas klara vissa samhällsfunktioner. De verkar båda inom ett befintligt ekono- 
miskt och politiskt system, och måste också utvecklas kontinuerligt eftersom urbanisering, (av)industrialisering, demografi, teknologisk utveckling med mera förändrar det omgivande samhället. Meadowcroft (2005) menar vidare att båda har normativa förståelsegrunder som kretsar kring förståelsen av rättvisa, medborgarskap, effektivitet, stabilitet och andra begrepp. Skillnaden mellan den traditionella välfärdsstaten och ekostaten är bland annat att åsikter om ekostaten är svårare att politiskt definiera på en höger-vänster-skala, och att klassiska välfärdsförespråkare, som fackförbund, ofta sägs vara motståndare till hårdare miljökrav då de är rädda för minskad tillväxt. Det nya paradigm som politiken följer sedan genomslaget för hållbar utveckling, där socialdemokrater och andra ofta säger sig förespråka en grön välfärd, innebär att det argumentet retoriskt sett inte längre fungerar på den svenska politiska arenan. Det skulle kunna ses som ett argument för att den ekologiska välfärdsstaten är en naturlig (i betydelsen självklar) följd av den sociala välfärdsstaten, och att välfärdsstaten anpassats till nuvarande samhällsfrågor. Dock ligger det kanske närmare till hands att tala om den hållbara välfärdsstaten, en stat som fokuserar på en sammanhållen hållbarhet skapad av en sund ekonomisk, social, kulturell och ekologisk politik?

En av teserna i den här artikeln är att miljöfrågan i nuläget är omöjlig att ignorera politiskt. Den har blivit en del av politikens kärnverksamhet, eller som Caldwell (2002, s. 225) skriver: "miljön har nu helt och hållet etablerat sig som en fråga samhället inte längre har råd att ignorera" (min översättning). Hållbar utveckling binder samman ekologiska och ekonomiska aspekter med sociala, vilket gör att miljö kan anses införlivat i välfärdstanken. Grön tillväxt har påkallats som ett sätt att resa sig ur ekonomiska problem, här exemplifierat med det gröna folkhemmet efter 1990-talskrisen. Som vi sett hamnar dock frågan i skymundan när ekonomiska kriser härjar som mest, och miljöfrågor är i nuläget i liten utsträckning inkorporerade i socialpolitiken nationellt och på EU-nivå (Caldwell 2002; Sommestad 20I2). I det politiska talet, här regeringsförklaringarna, kvarstår dock diskursen om hållbar utveckling genom grön tillväxt. 


\section{Konklusion}

Regeringsförklaringar uttrycker generella, breda målsättningar och utgångspunkter för politiken, inte konkreta mål eller löften. Därför går det inte att dra några slutsatser om vad som åstadkommits på området utifrån mitt källmaterial. Däremot är det möjligt att avläsa vad som är i den politiska hetluften, vilka områden som regeringen anser vara värda att lyfta fram och vilka de tror fångar allmänhetens intresse. Att miljöfrågan seglat upp som en viktig fråga för svensk politik är inte minst tydligt i det korta öppningsanförande som kungen håller innan statsministern läser sin regeringsförklaring. Sedan slutet av 1990-talet har kungen pratat om aktuella miljöfrågor i princip varje år. Detta kan också sägas symbolisera den normalisering och avideologisering som frågan genomgått. Att prata om miljö i dagens politiska klimat är inte ett uttryck för en radikal samhällskritik, utan snarare ett måste (Hajer 1995).

Som jag visat är varken miljöproblemen i sig eller dess globala karaktär något nytt, utan snarare något man talat om i 40 år. Vad som är nytt är sammankopplingen mellan miljö, välfärd och tillväxt och att välfärden måste anpassa sig till de nya globala kraven. I EU, även i Sverige, förespråkas tekniska innovationer och marknadslösningar sedan länge som nyckeln till miljö- och klimatproblem. Även om ekologisk moderniserings-teori inte längre understryker teknik och marknad som lösningen på miljöproblem på samma vis som när begreppet lanserades (Mol I999; Mol \& Sonnenfeld 2000), antar begreppet ofta den betydelsen i den politiska diskursen. Den politiska förståelsen ligger närmare den befintliga samhällsstrukturen och betonar teknikens och marknadens roll och den positiva relationen mellan miljöarbete och tillväxt mer än teorin någonsin gjort (se t.ex. Edman 1998). På EU-nivå ligger fokus på kostnadseffektivitet, en avreglerad energimarknad, låg grad av statsintervention och på konkurrens. Marknadspriser på koldioxid och handel med utsläppsrätter (som startade 2005) är det grundläggande sättet att handskas med klimatförändringar inom unionen (Sommestad 20I2). I Sverige är staten fortfarande en viktig aktör även vad gäller miljöfrågor, men dess roll beskrivs inte på samma sätt som i den traditionella välfärdsstaten. När lösningar frikopplade från statliga och kommunala institutioner i ökande utsträckning också förespråkas inom klassiska välfärdsdomäner 
såsom vård och omsorg (och när miljötänkandet efter inkluderingen av hållbar utveckling dessutom inte längre ses som ett hinder för tillväxten) underlättas sammanfogningen av sektorerna. Så till viss del har den klassiska välfärdspolitiken snarare närmat sig hur miljöpolitiken redan tidigare inrättats, med internationella sammanslutningar och avtal samt marknadsanpassade arbetssätt.

Miljö och naturresurser ses fortfarande i första hand som en funktion för att möjliggöra samhällets utveckling. Politiken strävar inte främst efter att värna miljön i sin egen rätt. Därmed förespråkas en antropocentrisk och modernistisk syn på frågan som rimmar väl med välfärdsstaten. EU:s inflytande på svensk politik har ökat och det internationella samfundet i form av FN spelar en viktig roll nationellt och lokalt. Samtidigt överlåts alltmer ansvar för välfärdstjänster till aktörer på den fria marknaden, och individens ansvar som konsument och medmänniska efterfrågas. På samma sätt hanteras miljö- och klimatfrågor, vilket innebär att en av artikelns huvudinsikter är att miljö- och klimatpolitiken har inlemmats i välfärdsstaten just därför att välfärdspolitiken omformulerats.

Nationalstaten har en mindre framträdande roll i dag som en följd av den globaliserade ekonomin och de allt mäktigare regionala och internationella aktörerna, vilket inte bara understryker vikten av samarbete över gränserna på en regional utan även på en lokal nivå. Eftersom det handlar om regionala och globala utmaningar krävs internationella sammanslutningar där nationalstater ingår som parter, men också transnationella samarbeten (formella och informella) där lokala arenor kopplas samman med varandra och den globala nivån. Även om EU-samarbetet innebär att en del makt förflyttats från den nationella arenan när Sverige och de andra medlemsstaterna införlivar alltmer av EU:s lagstiftning och policyer nationellt, framstår det som tydligt att staten ändå är en nyckelaktör i arbetet med miljö- och klimatfrågor. Det är nationalstaten som har förmågan att koppla samman olika nivåer, liksom att införa olika lagar och strategier. Även om statens tidigare allsidiga makt kommit att starkt begränsas genom kapitalets globalisering och ökade makt, kvarstår den politiska makten inom dess territorium (Lidskog \& Elander 20I2).

Synen på relationen mellan miljö och tillväxt, och sålunda också på huruvida miljömedvetenhet är att betrakta som ett "problem" för natio- 
nens ekonomiska välmående eller inte, har således förändrats över tid. I och med införandet av begreppen "hållbar utveckling" och "ekologisk modernisering" kom ömsesidig nytta att ses som allt viktigare, vilket också påverkat hur politik på och organisering av området utvecklats. Då ingen av de tongivande politiska partierna förespråkar lägre levnadsstandard eller dämpad tillväxt för miljöns skull blev det förändrade synsättet ett måste för att över huvud taget uttala sig miljöpolitiskt. I dag ser vi hur begreppen implementeras i en lång rad strategier och framtidsvisioner, på lokal, regional, nationell och internationell nivå. Hållbar utveckling är därmed att betrakta som kittet som binder samman välfärdsstaten och miljöpolitiken, vilket kan exemplifieras av de fyra strategiska områden som den tidigare socialdemokratiska regeringen såg som viktigast under mandatperioden 2002-2006: I) miljödriven tillväxt och välfärd, 2) god hälsa, 3) en samlad politik för hållbart samhällsbyggande, och 4) barnoch ungdomspolitik för en åldrande befolkning (Skr. 2003/O4:I29). De tre sistnämnda kan betecknas som redan införlivade i välfärden som begrepp. I och med införlivandet av hållbar utveckling sker detsamma med miljö, även om det bör understrykas att inkluderingen i den politiska diskursen inte per automatik innebär praktiska förändringar. Enligt Lidskog och Elander (2012, s. 422) har övergången från ord till handling inte varit så lyckad som politikerna gärna låter påskina: "retoriskt så kvarstår ett åtagande, men i policy och praktik har stötestenarna på vägen till hållbarhet visat sig besvärligare än vad som först antyddes av de djärva formuleringarna” (min översättning). I dag råder, som jag visar i den här artikeln, i princip konsensus om att hållbar utveckling ska utgöra ett politiskt mål nationellt, och det är den övergripande målsättningen även för FN och EU.

Den finansiella lågkonjunkturen på I990-talet kan som sagt betraktas som ett "möjlighetsfönster" för lanseringen av det gröna folkhemmet, även om begreppet i dag lever en undanskymd tillvaro. Den senaste stora ekonomiska krisen har inte alls på samma sätt knutits till gröna investeringar. Om detta beror på att en borgerlig regering satt vid makten vid tillfället, på att krisen inte slog så hårt mot Sverige, att krisen var av globalt mått eller om det beror på den avideologiserade roll som hållbar utveckling och miljöfrågan fått, är svårt att svara på. Att miljövänlighet inte ses 
som en uttalad lösning på finanskrisen i 20Io-talets regeringsförklaringar kan åtminstone delvis förstås som en följd av att hållbar utveckling alltsedan I990-talet presenterats som en självklart integrerad del av politiken och därför inte på samma vis kan introduceras som en revolutionerande idé i dag. Såren från krisen har dock knappt läkt, så en lansering av en ny vision om grön tillväxt är fortfarande möjlig.

\section{Referenser}

I den här artikeln har jag använt mig av följande regeringsförklaringar:

Prot. 1973/74:2 Prot. 1974/75:2 Prot. 1975/76:2 Prot. 1976/77:2 Prot. 1977/78:2

Prot. 1978/79:2 Prot. 1979/80:2 Prot. 1980/81:2 Prot. 1981/82:2 Prot. 1982/83:2

Prot. 1983/84:2 Prot. 1984/85:2 Prot. 1985/86:2 Prot. 1986/87:2 Prot. 1987/88:2

Prot. 1988/89:2 Prot. 1989/90:2 Prot. 1990/91:2 Prot. 1991/92:6 Prot. 1992/93:2

Prot. 1993/94:2 Prot. 1994/95:2 Prot. 1995/96:2 Prot. 1996/97:2 Prot. 1997/98:2

Prot. 1998/99:2 Prot. 1999/o0:2 Prot. 2000/01:2 Prot. 2001/02:2 Prot. 2002/03:2

Prot. 2003/04:2 Prot. 2004/05:2 Prot. 2005/06:2 Prot. 2006/07:6 Prot. 2007/08:2

Prot. 2008/09:2 Prot. 2009/10:2 Prot. 2010/II:2 Prot. 2011/I2:2 Prot. 2012/I 3:2

Prot. 2013/14:2 Prot. 2014/15:6

Anshelm, J. (1995) Socialdemokraterna och miljöfrägan. En studie av framstegstankens paradoxer. Stockholm: Symposion.

Anshelm, J. (2000) Mellan frälsning och domedag. Om kärnkraftens politiska idéhistoria i Sverige 1945-1999. Eslöv: Symposion.

Anshelm, J. (2002) "Det gröna folkhemmet. Striden om den ekologiska moderniseringen i Sverige", i Hedrén, J. (red.), Naturen som brytpunkt. Om miljöfrågans mystifieringar, konflikter och motsägelser. Stockholm: Symposion.

Barry, J. \& Eckersley, R. (red.) (2005) The state and the global ecological crisis. Cambridge: MIT Press.

Bennulf, M. \& Selin, H. (1993) "Miljö vs ekonomi. Blir vi mindre miljövänliga i kristider?", i Holmberg, S. \& Weibull, L. (red.), Perspektiv på krisen. SOM-undersökningen 1992. Göteborg: SOM-institutet.

Bro, A. (2000) Från hälsovård till miljöskydd. En historisk institutionell analys av kommunal ansvarsutveckling. Örebro: Universitetsbiblioteket.

Caldwell, C. (2002) "Green social welfare: an investigation into political attitudes towards ecological critiques and prescriptions concerning the welfare state", i Sykes, R., Bochel, C. \& Ellison, N. (red.), Social policy review I4. Developments and debates: 200I-2002. Bristol: Policy Press.

Christoff, P. (2005) "Out of chaos, a shining star? Toward a typology of green states", i Barry, J. \& Eckersley, R. (red.), The state and the global ecological crisis. Cambridge: MIT Press. 
Duit, A. (2002) Tragedins institutioner. Svenskt offentligt miljöskydd under trettio år. Stockholm: Statsvetenskapliga institutionen, Stockholms universitet.

Eckersley, R. (2004) The green state. Reethinking democracy and sovereignty. Cambridge: MIT Press.

Edberg, K. \& Fransson, A.-L. [kommande] "An offer they could not refuse? The Gotland local authority facing a Baltic Sea gas pipeline". Artikelmanus för publicering.

Edman, S. (1998) Världens chans. Ny möjlighet för Sverige - en bok om ekologi, teknik och solidaritet. Stockholm: Atlas.

Hajer, M. A. (1995) The politics of environmental discourse. Ecological modernization and the policy process. Oxford: Clarendon Press.

Harring, N., Martinsson, J. \& Rönnerstrand, B. (20II) "Vart tog klimatet vägen?”, i Holmberg, S., Weibull, L. \& Oscarsson, H. (red.), Lycksalighetens ö. Göteborg: SOMinstitutet.

Hassler, B. (2005) "The myth of sustainable development - environmental policy, practice and incentives in the Baltic Sea Region", i Bolin, G. m.fl. (red.), The challenge of the Baltic Sea Region. Culture, ecosystems, democracy. Huddinge: Södertörns högskola.

Hornborg, A. (2002) "Tillväxt och teknikutveckling som ymnighetshorn eller nollsummespel”, i Hedrén, J. (red.), Naturen som brytpunkt. Om miljöfrågans mystifieringar, konflikter och motsägelser. Stockholm: Symposion.

Jormfeldt, J. \& Sjöstrand, G. (20I4) "Miljö och ekonomisk tillväxt: attityder och samband", Surveyjournalen I, I, s. 34-45. DOI: http://dx.doi.org/IO.I5626/sj.20I4IO3

Karlsson, P. (2015) "Intern kritik mot MP-ledningen", Aftonbladet 3 juni 2015. URL: http://www.aftonbladet.se/nyheter/samhalle/article209039II.ab (Io juni 20I5).

Kärman, J. (20I4) "Bilden vi hade av oss var felaktig", Dagens Nyheter 27 november 2014. URL: http://www.dn.se/nyheter/politik/bilden-vi-hade-av-oss-var-felaktig/ (Io juni 2015).

Lidskog, R. \& Elander, I. (20I2) "Ecological modernization in practice? The case of sustainable development in Sweden", Journal of environmental policy \& planning I4, 4, s. $4 \mathrm{II}-427$.

DOI: http://dx.doi.org/IO.IO80/1523908X.20I2.737234

Lidskog, R. \& Sundqvist, G. (20II) Miljösociologi. Lund: Studentlitteratur.

Lundqvist, L. J. (2000) "Capacity-building or social construction? Explaining Sweden's shift towards ecological modernisation", Geoforum 3I, I, s. 2I-32. Dor: http://dx.doi.org/Io.IoI6/Soor6-7185(99)0oo4I-X

Meadowcroft, J. (2005) "From welfare state to ecostate”, i Barry, J. \& Eckersley, R. (red.), The state and the global ecological crisis. Cambridge: MIT Press.

Medina, E. (2013) Från "tyst vår" till "hållbar utveckling". En kritisk diskursanalys av miljöfrägans utveckling 1962-1987. Uppsala: Sociologiska institutionen, Uppsala universitet.

Moderaterna (2013) Moderaternas handlingsprogram. Ett modernt arbetarparti för hela Sverige.

URL: http://www.moderat.se/sites/default/files/attachments/handlingsprogram_-ett_modernt_arbetarparti_for_hela_sverige_20I3_2.pdf (I augusti 20I4). 
Mol, A. P. J. (1999) "Ecological modernization and the environmental transition of Europe: between national variations and common denominators", Journal of environmental policy \& planning I, 2, s. I67-I8I. DoI: http://dx.doi.org/I0.I002/(SICI)I522-7200(199909)I:2<I67::AID-JEPP22>3.0. $\mathrm{CO} ; 2-\mathrm{A}$

Mol, A. P. J. \& Sonnenfeld, D. A. (2000) "Ecological modernisation around the world: an introduction", Environmental politics 9, I, s. I-I4. URL: http://www.tandfonline.com/doi/abs/ıo.Io80/096440I00084I45IO (felaktig DOI, I6 mars 20I6)

Mol, A. P. J. \& Spaargaren, G. (2000) "Ecological modernisation theory in debate: a review", Environmental politics 9, I, s. I7-49. URL: http://www.tandfonline.com/doi/abs/ıo.I080/096440I00084I45II (felaktig DOI, I6 mars 20I6)

Persson, G. (2007) Min väg, mina val. Stockholm: Bonnier.

Proposition 2008/09:I62. En sammanhållen klimat- och energipolitik - Klimat. Regeringens proposition, överlämnad till riksdagen II mars 2009.

URL: http://www.regeringen.se/contentassets/cf4Id449d2aO47049d7a34foe23539ee/ en-sammanhallen-klimat--och-energipolitik---klimat-prop.-200809162 (II juni 20I5).

Regeringen (2013a) Stockholm +40 - partnership forum for sustainable development. URL: http://www.regeringen.se/sb/d/I59I/a/I84920 (I6 maj 20I3).

Regeringen (2013b) Nationellt klimatarbete. URL: http://www.regeringen.se/sb/d/8756 (4 februari 2013).

Regeringen (2015) Miljö-och energidepartementet. URL: http://www.regeringen.se/sb/d/I47I (I8 maj 20I5).

Rockström, J. (20I4) "Klimatet diskuteras inte i valrörelsen", Svenska Dagbladet I2 september 2014 . URL: http://www.svd.se/klimatet-diskuteras-inte-i-valrorelsen (Io juni 20I5).

Sandstedt, E. (200I) "Från social välfärd till hållbar välfärd”, i Lindbom, A. (red.), Den nya bostadspolitiken. Umeå: Boréa.

Skr. 200I/02:I72. Nationell strategi för hållbar utveckling. Regeringens skrivelse, överlämnad till riksdagen 14 mars 2002.

URL: http://www.regeringen.se/contentassets/24Ib29f58e444c8f9940f96d75bdbfbc/ nationell-strategi-for-hallbar-utveckling ( 16 maj 20I3).

Skr. 2003/04:I29. En svensk strategi för hållbar utveckling. Regeringens skrivelse, överlämnad till riksdagen 15 april 2004.

URL: http://www.regeringen.se/contentassets/63e668addcod42eI8d9c7de7fdc6f2db/ en-svensk-strategi-for-hallbar-utveckling ( 15 juni 2015).

Skr. 2005/06:I07. Tänk om! - En handlingsplan för hållbar konsumtion för hushållen. Regeringens skrivelse, överlämnad till riksdagen I6 mars 2006. URL: http://www.regeringen.se/contentassets/5ae459ad4bif432897I49b2ceadb58d9/ tank-om---en-handlingsplan-for-hallbar-konsumtion-for-hushallen-skr-200506I07 (I5 juni 20I5). 
Socialdemokraterna (2013) Framtidskontraktet. Politiska prioriteringar. URL: http://www.socialdemokraterna.se/var-politik/framtidskontraktet/ (29 januari 20I4).

Sommestad, L. (2012) "Climate policy and the social investment approach. Ttowards a european model for sustainable development", i Morel, N., Palier, B. \& Palme, J. (red.), Towards a social investment welfare state? Ideas, policies and challenges. Bristol: Policy.

Vail, B. (2008) "Ecological modernization at work? Environmental policy reform in Sweden at the turn of the century", Scandinavian Studies 80, I, s. 85-108. URL: http://www.jstor.org/stable/40920789

WCED (World Commission on Energy and Development) (1987) Our common future. FN-rapport. URL: http://www.un-documents.net/wced-ocf.htm (I8 maj 20I5).

While, A., Jonas, A. E. G. \& Gibbs, D. (2010) "From sustainable development to carbon control: eco-state restructuring and the politics of urban and regional development", Transactions of the Institute of British Geographers 35, I, s. 76-93.

DoI: http://dx.doi.org/I0.IIII/j.I475-566I.2009.00362.x 


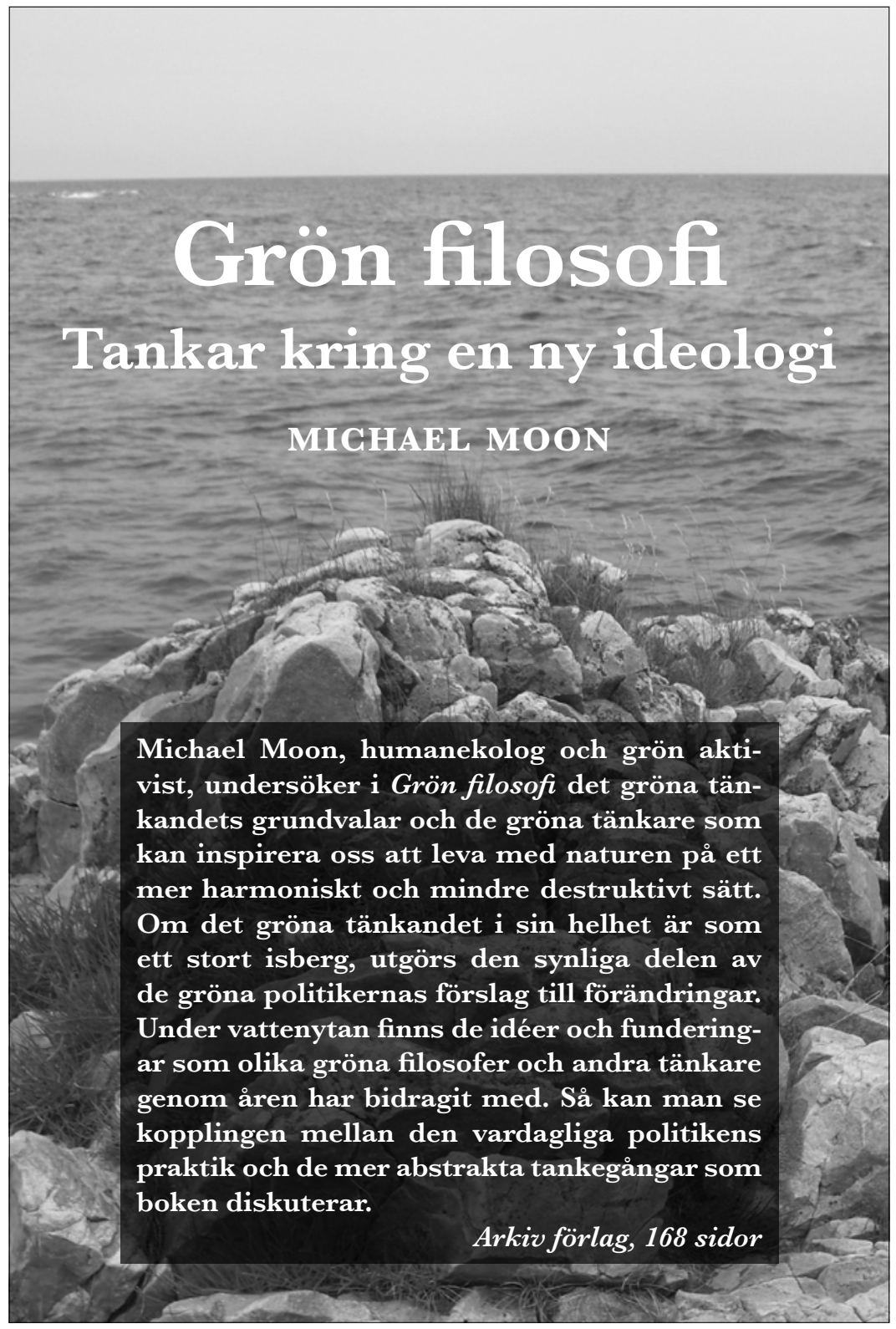

„Läs mer om boken påswww.arkiv.nuk 